\title{
ФОРМИРУЮЩИЙСЯ БАЛАНС СИЛ В «ИНДО-ПАЦИФИКЕ»
}

\author{
Леонова О. $\Gamma^{*}$
}

Понятие «Индо-Пацифика» (“Indo-Pacific”), недавно вошедшее в официальный политический лексикон, подразумевает акваторию Индийского и западной части Тихого океана и включает в себя все страны на их побережье. Оно отражает возросшую геополитическую роль Индийского океана в мировой политике и новую геополитическую реальность, где формируется новый баланс сил трех держав: Китая, Индии и США. В статье рассматриваются геополитические интересы данных стран в Индийском океане, цели их политики в регионе, особенности стратегии относительно реализации поставленных иелей. Анализ целей, геополитических интересов и стратегий этих стран в борьбе за влияние в Индийском океане показывает, что они противоречат друг другу и вступают в конфликт, в котором роль арбитра и гаранта безопасности намерень играть США.

Формируюшийся узел геополитических противоречий в регионе Индийского океана ведет к нарушению баланса сил и чреват возникновением конфликта. Выявлены возможные последствия данной ситуации, которые имеют как региональный, так и глобальный аспект.

Ключевые слова: «Индо-Пацифика», Индийский океан, Китай, Индия, США, национальные интересы, цели политики, стратегия, позиции сторон, проект «Жемчужное ожерелье».

The concept of 'Indo-Pacific' reflects the increased geopolitical role of the Indian Ocean in world politics and a new geopolitical reality, where a new balance of power is being formed between the three states: China, India and the United States. The article reveals the geopolitical interests of these countries in the Indian Ocean, the goals of their policy in the region, as well as the specifics of the strategy for implementing these goals. The analysis of the goals, geopolitical interests and strategies of these countries in the struggle for influence in the Indian Ocean shows that they contradict each other and come into a conflict in which the United States intent to play the role of arbiter and guarantor of security.

The emerging knot of geopolitical contradictions in the region of the Indian Ocean leads to a violation of the balance of power and is fraught with the emergence of a conflict. The identified negative consequences of this situation have both a regional and global aspect.

Keywords: 'Indo-Pacific', Indian Ocean, China, India, Pakistan, the USA, national interests, policy goals, strategy, positions of the parties, 'The String of Pearls' project.

\section{Концепция «Индо-Пацифика»}

Понятие «Индо-Пацифика» (“Indo-Pacific”), недавно вошедшее в официальный политический лексикон, подразумевает акваторию Индийского и западной

* Леонова Ольга Георгиевна - д. полит. н., профессор факультета глобальных процессов МГУ имени М. В. Ломоносова. E-mail: politolga@gmail.com.

Век глобализации 2/2021 75-88

DOI: $10.30884 / v g l o b / 2021.02 .06$ 
части Тихого океана и включает в себя все страны на их побережье [Kumar et al. 2020: 218]. Сегодня этот геополитический ареал стал объектом столкновения стратегических интересов Китая, Индии, Пакистана и США. Происходит формирование нового статуса Индийского океана как геополитического и геоэкономического центра притяжения интересов глобальных держав. Понятие «Индо-Пацифика» показывает, как стремительно меняется геополитический ландшафт в эпоху глобализации [Pan 2014: 458], описывает регион, в который смещается глобальный центр тяжести глобального мира [Singh 2016: 96], и иллюстрирует новую геополитическую реальность, формирующуюся в этом морском пространстве [Scott 2012: 87].

Концепция «Индо-Пацифика» отражает быстро меняющиеся геополитические ориентиры в глобализирующемся мире [Naidu 2014: 102] и обретение рядом региональных держав нового, глобального статуса. Этот морской суперрегион с центром в Юго-Восточной Азии стал особенно актуальным в связи с возвышением Китая и Индии, претендующих на статус глобальных держав. Сегодня «ИндоПацифика» приобретает большое стратегическое значение, поскольку здесь проходит дуга торговых путей, энергетических потоков, дипломатических и стратегических связей между двумя океанами. Ускорение экономической интеграции и связей в области безопасности между западной частью Тихого океана и регионом Индийского океана создают там единую геоэкономическую и стратегическую систему [Medcalf 2014: 470-472].

Концепт «Индо-Пацифика» показывает тенденцию формирования новой региональной архитектуры, которая является результатом увеличения торговых потоков, производственных и инвестиционных связей в районе между Индийским и Тихим океанами [Chacko 2014; Pardesi 2020: 124, 125, 138].

Недавно в США признали неадекватность термина АТР (Азиатско-Тихоокеанский регион), который якобы не способен отразить и охватить геополитические и внешнеполитические цели их политики в Азии [New... 2016: 2]. Это привело к идее расширить понятие АТР (Азиатско-Тихоокеанский регион) до «Индо-АзияПасифик» ('Indo-Asia-Pacific') [Ibid.: 17]. Такой контекст позволял Соединенным Штатам закрепить свой статус регионального лидера и расширить это лидерство за пределы зоны АТР и Азии [Scobell 2020: 14-15].

Термин «Индо-Азия-Пасифик» с точки зрения геоэкономики звучал вполне правомерно, однако президент Д. Трамп предпочел сократить его до «ИндоПацифика» (“Indo-Pacific”), подчеркнув тем самым новую стратегическую область интересов США в паназиатском регионе и их статус в качестве резидентной державы в Азии. В результате понятие "Indo-Pacific" было включено в Стратегию национальной обороны США 2018 г. [Summary... 2018: 9]. В июне 2018 г. Тихоокеанское командование CШA (the U.S. Pacific Command) было переименовано в Индо-Тихоокеанское командование (the U.S. Indo-Pacific Command) [Pant, Rej 2018: 47].

С точки зрения Индии, давно превалирующая конструкция «Азиатско-Тихоокеанский регион» была неадекватной и неоднозначной и не отражала ее растущую роль в Азии [The Origin... 2018]. Поэтому концепция «Индо-Пацифика» была там с готовностью принята, поскольку она ставила страну фактически в центр этого геополитического ареала. Индия включила ее в свою Стратегию морской безопасности в 2015 г. [Ensuring... 2015] и Объединенную военную доктрину в 2017 г. [Joint... 2017]. 
В иелом конщепщия «Индо-Пацифика» отражает возросшую геополитическую роль Индийского океана в мировой политике.

Данная тема привлекла к себе внимание зарубежных экспертов во втором десятилетии XXI в. В «Белой книге» Австралии в 2013 г. зона стратегических интересов страны была названа «Индо-Пацифика». Так данный термин впервые был введен в официальный политический лексикон [Medcalf 2014: 470]. С тех пор этот концепт получил широкое распространение в политическом и научном дискурсе [Scobell 2020: 15].

Конщепчия «Индо-Паџифика» появилась недавно и стала актуальной по ряду причин.

Во-первых, это попытка Запада противопоставить ее китайскому проекту «Один пояс - один путь», который грозит разрушить имеющуюся архитектуру безопасности в регионе.

Во-вторых, относительный спад в западной экономике и подъем Китая и Индии как крупных экономических держав изменили глобальные модели морских путей сообщения. Теперь Индийский океан стал важным торговым путем, связующим два континента: Африку и Азию. Через этот регион проходят морские пути, имеющие важное геоэкономическое и военно-стратегическое значение, поскольку по ним осуществляются перевозки энергоносителей и сырья из африканских стран в Азию и технологий из азиатских стран в Африку.

В-третьих, существует тесная взаимосвязь между статусом государства в глобальной иерархии и океаном. Выход к океану и близость морских путей способствуют повышению роли страны в мировой экономике. Так, термин «ИндоПацифика» отражает повышение роли Индии как формирующейся глобальной державы и ожидания, что эта страна будет играть ведущую роль в морской политике и обеспечении экономического роста и развития региона.

В-четвертых, используемый ранее конструкт АТР (Азиатско-Тихоокеанский регион) стал уже не совсем адекватным тем процессам, которые протекают в Азии в целом, особенно в Южной и Юго-Восточной ее частях. Данный термин слишком размыт (до сих пор не утихают споры о том, какие страны следует сюда включать), кроме того, он не отражает той роли, которую Индия стала играть в этом регионе.

Морская линия простирается от Западной Азии (Иран и Сирия) до СевероВосточной Азии (включая Корейский полуостров). Это заставило аналитиков искать подходящий термин для данной региональной геополитической структуры. «Азия»- слишком широкое понятие и ассоциируется с континентом. Термин АТР (Азиатско-Тихоокеанский регион), обычно употребляемый для обозначения стран, расположенных по береговой линии Тихого океана, в том числе на побережье Латинской Америки, не совсем уместен в данном случае. «Индо-Пацифика» (объединенная территория Индийского и западной части Тихого океанов) кажется более подходящим понятием.

Во втором десятилетии XXI в. геополитическая, геоэкономическая и военностратегическая взаимосвязь между Индийским океаном и западной частью Тихого океана стала очевидной. Так появился термин «Индо-Пацифика»- актуальное понятие в современном стратегическом и геополитическом дискурсе. 


\section{Конфликт интересов в «Индо-Пацифике»}

«Индо-Пацифика» начинает играть все более важную роль в мировой политике. А в регион Индийского океана смещается конфликт интересов ведущиих держав: Китая, Индии и США. Эти интересы в корне противоречат друг другу [Неуdarian 2020: 9-11].

\section{Геополитические интересы Китая в регионе}

Ранее Индийский океан рассматривался Китаем как стратегическая периферия. Что касается его удаленности от границ страны, то это действительно географически периферийная для Китая территория. Но с точки зрения национальных интересов КНР этот регион приобретает для него все более важное стратегическое значение [Ibid.: 2].

Китай утверждает, что его политическая стратегия в Индийском океане имеет сугубо мирную цель. Она заключается лишь в том, чтобы обеспечить себе альтернативные морские и торговые пути и тем самым уменьшить свою зависимость от Малаккского пролива [Pardesi 2020: 135-136]. Этот пролив, через который идет большой поток грузов в Китай, в основном энергоносителей и продовольствия, действительно является узкой точкой, к тому же контролируемой Военноморскими силами США. Теоретически в любой момент они могут своими кораблями заблокировать пролив, что приведет к энергетическому и продовольственному кризису в КНР. Все действия Соединенных Штатов в этом регионе традиционно интерпретируются Китаем как направленные против их национальных интересов [Scobell 2020: 8]. Поэтому КНР действительно вынуждена искать альтернативные морские и торговые пути [Jakobson, Medcalf 2015: 4, 17]. Этой же цели служит и китайский проект «Морской шелковый путь», который является составной частью концепции «Один пояс - один путь». Реализация этого проекта позволяет Китаю укрепить свои позиции в регионе, где всегда традиционно доминировала Индия, а также утвердить свой статус морской державы [Jakobson, Medcalf 2015: 17, 19].

\section{Геополитические интересы Индии в регионе}

Официальная позиция Индии по Индийскому океану базируется на принципах либерально-демократического международного порядка. Ее геополитические интересы обусловлены тем, что последние двадцать лет здесь беспрецедентно развивалась международная торговля, росли инвестиции и производство. Поэтому Индия особенно заинтересована в сохранении статус-кво в этом регионе.

Необходимость сохранения и укрепления своего традиционного влияния в этом ареале, глобальные амбиции [Li 2018] и интересы политических элит оказали сильное влияние на формулирование геополитических интересов и целей Индии в «Индо-Пацифике». Кроме того, концепт «Индо-Пацифика» конституирует Индию как центральный актор в этом обширном экономически и стратегически важном регионе [Barthwal-Datta, Chacko 2020: 258]. Однако со стороны Китая она сталкивается с вызовами своей национальной безопасности и угрозами статускво. Индия считает, что Китай угрожает ее региональному лидерству в Индийском океане [India... 2018].

Индия имеет все основания сомневаться в миролюбивых планах Китая и намерена защищать свои интересы в Индийском и западной части Тихого океана, 
укрепляя свои военно-морские силы и оснащая их ядерным оружием. Однако индийский флот не так хорошо оснащен, как китайский, потому Пекин не рассматривает его как серьезную угрозу и препятствие своим целям и планам.

\section{Геополитические интересы США в регионе}

Соединенные Штаты Америки традиционно включали Азиатско-Тихоокеанский регион, претендующий на статус центра силы глобального мира, в сферу своих национальных интересов. Но в XXI в. подъем таких стран, как Индия, Пакистан, Индонезия, Шри-Ланка, Мьянма, Оман, и изменение баланса сил в регионе привели к тому, что именно Индийский океан приобрел для них особое значение [Kaplan 2010].

Возвышение Китая, модернизация его вооруженных сил и проведение им более активной и жесткой политики на международной арене, в частности в Индийском океане, вступает в конфликт с интересами США, диктует необходимость противостоять усилению влияния Китая и сохранить свои лидирующие экономические, политические и военно-стратегические позиции в регионе.

В последние годы администрация Д. Трампа подняла Индо-Тихоокеанский регион до регионального приоритета высшего уровня, что и отражено в Стратегии национальной безопасности США 2018 г. Стратегия описывает «ИндоПацифику» как регион, в котором происходит геополитическая конкуренция стран между их представлениями о мировом порядке [Summary... 2018].

Концепция «Индо-Пацифика» позволяет Соединенным Штатам провести здесь перебалансировку власти и влияния с целью укрепления своего статуса регионального гегемона [Pardesi 2020: 124]. Стратегия США в «Индо-Пацифике» направлена на противостояние Китаю, что позволяет подчеркнуть роль США как гаранта безопасности не только стран АТР, но также и государств, расположенных на берегах Индийского океана, стимулируя их тем самым на более тесное взаимодействие и сотрудничество с Соединенными Штатами в качестве союзников и партнеров. При этом США рассчитывают опереться на Индию как на своего партнера в противостоянии с Китаем для укрепления геостратегических альянсов в этом регионе и стремятся развивать с ней партнерские связи в сфере безопасности и обороны [Kumar et al. 2020: 216-219, 227].

\section{Цели сторон}

Цели политики сторон в этом регионе вытекают из их геополитических интересов.

\section{Цели Китая}

Одна из важных целей Китая - активизировать свое участие в глобальном управлении в качестве глобальной державы ${ }^{* *}$. Для достижения этой цели КНР расширяет свою активность в мировой политике. Если раньше приоритетным ин-

** «Отличительным признаком глобальной державы является способность контролировать и воздействовать на внутреннюю и внешнюю политику не только сопредельных стран - соседей по региону, но и государств, расположенных в отдаленных от их территории частях земного шара» [Ильин, Леонова 2017: 39]. 
струментом была торгово-экономическая сфера, сегодня этого уже недостаточно. Реализация статуса глобальной державы требует более активных действий в сфере обеспечения региональной безопасности и участия в выстраивании региональной архитектуры суперрегиона «Индо-Пацифика».

1) Несомненно, важная цель Китая - обеспечение безопасности своих морских торговых путей в Индийском океане. Индийский океан и прилегающие к нему воды являются важным маршрутом для торговых судов Китая, от которых зависит снабжение страны важными для ее жизнедеятельности ресурсами. Сегодня Китай является главным партнером большинства африканских стран, потеснив с этой позиции США. С Африканского континента в КНР морским путем идет мощный поток товаров и сырья. Магистраль Юг - Юг приобретает для этой страны все более важное стратегическое значение. Поэтому Китаю действительно необходимо в целях защиты своей безопасности контролировать ситуацию и не допустить попыток ограничить доступ к этим морским путям.

2) Экономике Китая для стимулирования дальнейшего экономического роста нужны энергетические ресурсы. Большая часть нефти, импортируемой Китаем, проходит через Индийский океан, особенно через Малаккский пролив, который контролирует военно-морской флот США. В любой момент при обострении отношений двух стран он может заблокировать этот пролив, обрекая Китай на продовольственный и энергетический голод. Поэтому важной целью КНР является создание альтернативных транспортных маршрутов для импорта нефти, в том числе через Индийский океан, минуя Малаккский пролив. Это делается для того, чтобы уменьшить зависимость от данного пролива, являющегося главным узким местом на трансокеанских транспортных маршрутах, и обеспечить Китаю стратегическую и ресурсную безопасность.

3) Еще одна цель Китая - это военно-стратегическое окружение Индии давнего соперника и конкурента [Scott 2012: 94-95]. Это могло бы гарантировать победу КНР в борьбе за влияние в важной для него «стратегической периферии» - в Индийском океане.

Сдерживать возвышение Индии, создавать для нее новые вызовы безопасности в Индийском океане и тем самым помешать ей обрести статус глобальной державы - такая цель стоит за всеми действиями Китая в этом регионе. Например, Мальдивские острова всегда считались естественным продолжением индийского пространства безопасности. Однако строительство на одном из них китайской логистической базы является фактически нарушением морского пространства Индии и позволит Китаю контролировать стратегический коридор, который связывает западную и восточную береговые линии этой страны.

\section{Цели Индии}

Такая активность настораживает Индию, поскольку страны побережья Индийского океана всегда традиционно находились в орбите ее геополитического влияния. Это также не нравится США, которые справедливо видят в таких действиях Китая проявление еще одной попытки одержать победу в соперничестве в регионе за сферу своих интересов. Присутствие китайской военно-морской ядерной державы создает тревожную атмосферу в регионе Индийского океана. В этой ситуации главной целью Индии является сохранение статус-кво в регионе, в котором пролегают важные торговые пути из Африки в Индостан. 
Во-первых, в рамках сотрудничества Индии в формате ИБСА (трехсторонний диалоговый Форум Индии, Бразилии и ЮАР) и с другими африканскими странами по этим торговым путям везут ресурсы, необходимые для развития быстрорастущей экономики страны: энергоносители, сырье (в том числе для ядерной энергетики), биотопливо, что обеспечивает стратегически важное взаимодействие Индии по линии Юг - Юг.

Системные, региональные, национальные и внутренние динамичные изменения в Индии и Африке в период после окончания холодной войны сформировали условия, в которых актуальность отношения между ними стала стремительно повышаться. С каждым годом индийско-африканские связи приобретают все большее стратегическое значение, и из периферийных они постепенно становятся потенциально приоритетными. Индия не хочет допустить роста присутствия в этом регионе Китая, так как это создает угрозу контроля с его стороны стратегически важных для нее морских торговых путей.

Во-вторых, данный регион Индия всегда рассматривала как традииионную геополитическую зону своих интересов и влияния. Большинство стран побережья Индийского океана, близкие к ней не только географически, но цивилизационно и культурно, исторически являлись союзниками и партнерами Индии. Это давало ей возможность позиционировать себя как региональную державу, что обеспечивало почетный статус в глобальной иерархии держав. Потеря таких союзников означала бы для Индии понижение ее статуса в глобальной политике и повышало бы ее военно-стратегическую, геополитическую и геоэкономическую уязвимость. Поэтому цеелью Индии является сохранение этой зоны своего геополитического влияния.

\section{Цели США}

В сложившейся ситуации перед США стоит цель активизировать свою политику в «Индо-Пацифика», чтобы усилить свое влияние в новой региональной системе международных отношений. Стратегия США в «Индо-Пацифика» направлена на предотвращение китайского доминирования в Индо-Тихоокеанском регионе путем осторожной стратегии баланса сил в Азии [Grieco 2018].

Важной задачей для США является наращивание своего политического и военного присутствия на границах двух океанов, поддержание союзнических отношений с традиционными партнерами США в Северо-Восточной Азии (Японией и Республикой Корея), Южной Азии (с Пакистаном и Индией) и Юго-Восточной Азии. Это будет способствовать укреплению позиций Вашингтона в регионе «Индо-Пацифика» для того, чтобы нейтрализовать действия и растущую мощь Китая.

Для укрепления позиций лидера Соединенные Штаты и в дальнейшем будут продолжать проведение активной внешней политики и наращивать потенциал экономического и силового влияния в регионе. Таким образом, диаметральная противоположность целей основных акторов в этом регионе Индийского океана неизбежно приводит к столкновению их национальных интересов. В соответствии со своими целями данные страны используют разные стратегии в «Индо-Пацифика» для их достижения. Рассмотрим эти стратегии и позиции сторон. 


\section{Проект «Жемчужное ожерелье»}

Чтобы закрепиться в Южной Азии и в Индийском океане, Китай использует тонкую и многовекторную стратегию, которая представляет сочетание экономического патронажа, политической поддержки и достаточно жесткой военной тактики в отношении стран, постепенно впадающих в зависимость от него.

С одной стороны, Китай щедро предоставляет другим странам инвестиции в экономику и инфраструктуру, обеспечивая материальную базу их развития и модернизации, создавая новые рабочие места и обеспечивая им высокие темпы роста. Такие действия КНР стимулируют торгово-экономическое развитие «ИндоПацифики», а учитывая масштаб этого региона и его роль в глобальных экономических процессах, вносят вклад в развитие мировой экономики.

С другой стороны, это становится инструментом реализации геополитических целей КНР, так как постепенно ведет к «китаезации» экономик данных стран. Многие инвестиционные проекты Китая в ИТР имеют и политический характер, так как позволяют ему расширять свое влияние в регионе и становятся эффективными инструментами «мягкой силы».

Во-первых, сегодня страны Южной Азии закупают в большом количестве китайские военно-морские средства и вооружения, иногда участвуют в совместной разработке боевых кораблей и подводных лодок. Во-вторых, китайские инвестиции в морскую инфраструктуру этих стран, особенно в их глубоководные порты, формируют их экономическую и военно-стратегическую зависимость от Китая. Для закрепления своего влияния в Индийском океане Китай строит цепочку морских портов в прибрежных океанических странах: в Мьянме, Пакистане, Бангладеш и Шри-Ланке [Mathur 2014]. Данный проект получил название «Жемчужное ожерелье» (“a string of pearls").

КНР направляет солидные инвестиции на проекты развития, модернизации, строительства новых морских портов и оснащение их оборудованием на северной границе региона «Индо-Пацифика». Данная стратегия - «Жемчужное ожерелье» стала олицетворением военных и торговых амбиций Китая, которые он реализует под видом экономической помощи странам, расположенным на побережье океана. Фактически Китай создает систему логистических и военно-стратегических пунктов под своим патронажем, ставя данные страны во все большую экономическую зависимость от своих инвестиций [Mukherjee 2018]. Китай утверждает, что делает это исключительно в мирных целях [Jakobson, Medcalf 2015: 19]. Однако западные эксперты считают, что он использует экономические стимулы, чтобы «выманить» страны из стратегической орбиты Индии, что также является его важной задачей.

Вполне возможно двойное использование этих портов, в том числе и в военно-стратегических целях, например, для наблюдения за передвижением военноморских сил других стран, прежде всего США и Индии, в данном регионе. При необходимости эта система портов может быть использована и в чисто военных целях как логистическая структура для снабжения военно-морских сил КНР.

«Жемчужное ожерелье», состоящее из системы морских портов, как бы обнимает азиатское побережье Индийского океана, что ставит Китай в очень выгодное стратегическое положение. Он получает доступ к портовым структурам в ключевых точках Индийского океана не только для реализации собственных 
экономических интересов, но и для усиления своего стратегического присутствия. И по мере усиления мощи ВМФ Китая в Индийском океане будет возрастать уязвимость Индии, несмотря на ее очевидные преимущества в плане географического положения в регионе [Dutta 2016].

Концеппия «Жемчужного ожерелья» - это стратегия формирования геополитического доминирования Китая в регионе «Индо-Пациффика».

Используя «Морской шелковый путь» в качестве базовой опоры своей стратегии, Китай постепенно устанавливает взаимозависимость между собой и различными государствами Южной Азии. Это, в первую очередь, касается Шри-Ланки, которая, обремененная огромным китайским долгом, отдала в аренду проект строительства морского порта Хамбантота китайским государственным структурам.

Другая опорная точка китайской стратегии - Пакистан, для которого Китай разрабатывает проект морского порта Гвадар в рамках Китайско-пакистанского экономического коридора. Еще одной «жемчужиной» в цепочке геополитического доминирования Китая являются Maльдивы, архипелаг, лежащий на краю так называемой «исключительной экономической зоны Индии». Это знаменует собой переломный момент в китайско-индийской морской динамике. Поскольку Мальдивские острова представляют собой буферную зону, окружающую стратегическое морское пространство Индии, постоянное военное присутствие здесь Китая вызывает ее серьезную озабоченность.

\section{Стратегия Индии по реализации поставленных целей}

Реализация Китаем проекта системы морских портов по всему побережью Индийского океана вызвала закономерную тревогу у Индии. Эта страна дает жесткие оценки региональной ситуации и политике Китая в военно-морской области в Индийском океане. Там полагают, что Китай стремится минимизировать влияние Индии в Индийском океане путем установления дружественных отношений со всеми своими морскими соседями, создавая тем самым ощутимую угрозу с моря.

Принятая в 2015 г. Стратегия морской безопасности (“Indian maritime security strategy”) свидетельствует, что Индия в ответ на возрастающую активность Пекина в «Индо-Пацифике» вынуждена пересматривать свою военно-морскую политику в этом регионе. Ее главная цель обозначена уже в самом названии Стратегии - «Обеспечение безопасных морей» (“Ensuring secure seas”), а центральной задачей является предотвращение конфликтов путем «надежного и минимального ядерного сдерживания» (“а credible minimum deterrent”), в котором ведущая роль отводится подводным лодкам, оснащенным баллистическими ракетами [Ensuring... 2015: 48].

Стратегия морской безопасности 2015 г. расширяет зоны геополитического интереса Индии на этой территории, которая включает в себя юго-западную часть Индийского океана и узловые точки морских путей, идущих через этот океан вплоть до восточного побережья Африки [Ibid.: 32]. Озабоченность индийской стороны настолько серьезна, что Индия приступила к осуществлению плана по строительству собственного «Жемчужного ожерелья» или, по крайней мере, «нитки жемчуга» в Индийском океане. Так, в 2001 г. были созданы стратегиче- 
ские военно-морские базы на Андаманских и Никобарских островах. Но дальнейшего развития эта стратегия пока не получила.

Индия оказалась в затруднительной ситуации. Ее неспособность выстраивать эффективные экономические и политические взаимоотношениями с соседними странами создала вакуум лидерства в регионе, который довольно быстро заполнил Китай. Индийские лидеры не смогли остановить падение влияния своей страны в ареале «Индо-Пацифика». Индии же предстоит приложить немалые усилия, чтобы исправить свои прошлые ошибки и разработать эффективную стратегию восстановления своего влияния в регионе. У нее есть два пути. Первый - смириться с экономическим, политическим, военно-стратегическим лидерством Китая в регионе, занять более низкое место в региональной иерархии держав, позволить Пекину вытеснить ее из всех традиционных сфер влияния.

Другой путь для Индии - предпринимать активные усилия для сохранения своего стратегического пространства в регионе, проводить стратегию сдерживания Китая, расширять свое морское присутствие в «Индо-Пацифике», противодействовать реализации проекта «Жемчужное ожерелье». Но это более затратный, трудный и, значит, менее вероятный путь.

Сегодня Индия фактически стратегически изолирована в регионе «ИндоПацифика» и поэтому не может являться балансиром растущего влияния Китая, его финансовой и военной мощи. Ситуация вынуждает Индию отойти от своей традиционной политики стратегической сдержанности и традиций неприсоединения и сделать свой геополитический выбор. В любом случае Индию уже нельзя рассматривать как второстепенного игрока на международной арене. Все ее действия в «Индо-Пацифике» будут направлены на то, чтобы доказать свой статус глобальной державы.

\section{Стратегия США}

Еще в недавнем прошлом ареал «Индо-Пацифика» не был среди приоритетов внешней политики США. Сегодня они заостряют свое внимание на неизбежности стратегической конкуренции с Китаем за влияние в этом регионе и необходимости борьбы за расширения своего присутствия в нем.

Как сказано в Стратегии национальной обороны США 2018 г., их целью является создание «свободного и открытого» региона «Индо-Пацифика» ('A free and open Indo-Pacific region'), поддержание стабильности и обеспечение свободного доступа ко всем прибрежным территориям ('common domains'). Для достижения этих целей необходимо укрепление альянсов и партнерских отношений в ИндоТихоокеанском регионе, строительство «сетевой архитектуры безопасности» ('a networked security architectur'), развитие двусторонних и многосторонних отношений в области безопасности [Summary... 2018].

В США пока еще не сложилась комплексная стратегия политики в этой новой геополитической реальности. Если судить о высказываниях Д. Трампа по поводу американской стратегии в «Индо-Пацифике», например, во время его визита во Вьетнам в ноябре 2017 г., или Рекса Тиллерсона накануне его визита в Индию в октябре 2017 г., очевидно, имеется в виду «перебалансировка» взаимоотношений США с ведущими странами региона. При этом силовая составляющая американской политики в ареале «Индо-Пачифика», по-видимому, будет доминирующей. 
В США считают, что присутствие их военно-морских сил в регионе «ИндоПацифика» будет играть сдерживающую роль для геополитических амбиций трех стран - Китая, Индии и Пакистана и поможет держать ситуацию под контролем. В связи с этим можно ожидать наращивания количества американских боевых кораблей и вооружений в данном регионе. При этом возглавляемая Соединенными Штатами в АТР сеть двусторонних альянсов в настоящее время уступает место разнообразному набору объединений и коалиций для решения все более сложных вопросов региональной безопасности.

\section{Заключение и выводы}

Таким образом, главный вектор взаимодействия глобальных держав смещается в акваторию Индо-Тихоокеанского пространства, где появляются новые угрозы, выстраивается новая архитектура безопасности и формируется тугой узел геополитических противоречий, чреватый ядерным конфликтом.

Эта ситуаиия может иметь следуюшие последствия. Во-первых, возможны постепенная милитаризация региона, наращивание военно-морского ядерного потенциала сторон, несоблюдение международного ядерного протокола и гонка вооружений в Южной и Юго-Восточной Азии.

Во-вторых, при дальнейшем обострении ситуации возможный конфликт вполне может быть связан с применением ядерного оружия.

При этом Китай проводит политику в рамках своей ядерной доктрины ограниченного сдерживания, а Индия - согласно доктрине надежного минимального сдерживания. Индия придерживается принципа неприменения ядерного оружия первой. Он закреплен в ядерной доктрине 2003 г., однако в сложившейся ситуации нельзя исключать изменение ее позиции по данному вопросу. Так, в «Объединенной доктрине вооруженных сил Индии» (“Joint Indian Armed Forces Doctrine") 2017 г. (раздел "Conflict Prevention", пункт 21) вместо фразы «надежное минимальное сдерживание» (“a credible minimum deterrent" - как было ранее сформулировано в «Стратегии морской безопасности 2015 г.» (“Ensuring Secure Seas: Indian Maritime Security Strategy") [Ensuring... 2015] используются просто «сдерживание» (“the policy of deterrence") и словосочетание «надежный потенциал сдерживания» (“a credible deterrence capability”) [Joint... 2017: 21].

Это показывает определенные изменения в ядерной доктрине Индии (“a shift in India's nuclear posture"), что можно трактовать и как отказ в случае необходимости от принципа неприменения ядерного оружия [Rajeev 2017].

B-третьих, многие в Индии серьезно полагают, что открытый конфликт с Китаем неизбежен. Борьба за безопасность стратегически важных для Китая и Индии торговых путей в Индийском океане и их контроль являются одной из главных движущих сил формирующегося конфликта.

Усилия обеих стран по наращиванию своего военно-морского ядерного потенциала вызывают тревогу у США. Это неизбежно приведет к тому, что Соединенные Штаты, как и в случае с Юго-Восточной Азией, добровольно возьмут на себя роль гаранта безопасности, а значит, будут усиливать свое военное присутствие в регионе. Во взаимоотношениях этих держав ввиду большого разрыва их экономического и военного потенциала имеется стратегический диссонанс, который может спровоцировать открытую военную конфронтацию. Вряд ли эти стра- 
ны захотят эскалации еще одного конфликта. Но наряду с очевидным нежеланием этих стран развязывать горячую войну вполне возможно начало «ядерного диалога» в целях обеспечения баланса сил и «укрепления стабильности».

Конкурентная борьба стран - Китая, Индии и США за сферы влияния будет определять будущее Индо-Тихоокеанского региона [Mohan 2012]. Эта конкуренция может привести к нарушению геополитического и геостратегического баланса сил в регионе Индийского океана [Doyle, Rumley 2020]. Будущее покажет, чем станет ИТР: ареной конкуренции глобальных держав с ядерным оружием в их арсенале как аргументом их силы или регионом сотрудничества, региональным кластером экономического рывка, в обеих случаях имеющими глобальную проекцию. Заинтересованным странам, в число которых, несомненно, входит и Россия (как стратегический партнер Китая и Индии), необходимо принять значительные меры для сдерживания формирующегося конфликта интересов.

Одна из главных целей такой политики - сохранение статус-кво в Индийском океане. Это было бы выгодно всем сторонам назревающего конфликта. Нынешний статус-кво включает активную торговлю, свободное морское судоходство, совместный поиск альтернативных нефтяных и торговых путей, продолжение диалога по проблеме ядерного оружия. Это может послужить важной отправной точкой для начала сотрудничества и снижения существующей напряженности.

Но похоже, что Китай не хочет сохранять статус-кво в Индийском океане, Индия не может ему помешать, а США будут бороться за изменение ситуации в свою пользу. США не смогут или, учитывая их противоречия с Китаем, не захотят играть роль миротворцев в конфликте этих двух стран, а воспользуются ситуацией, чтобы обернуть ее в свою пользу. Поэтому крайне важно, чтобы обе страны осознали необходимость сближения позиций и попытались урегулировать свои разногласия в регионе «Индо-Пацифика» на двустороннем уровне. А Россия могла бы (и имеет такое право) как член БРИКС и ШОС (Шанхайской организации сотрудничества), куда входят обе державы, сыграть роль посредника на переговорах и предложить свои меры урегулирования ситуации. Кроме того, концепция «Индо-Пацифика» должна войти в новую редакцию Концепции внешней политики РФ, и нашей стране необходимо четко определить свою позицию в этой конфликтной ситуации.

\section{Jumepamypa / References}

Ильин И. В., Леонова О. Г. Политическая глобалистика. М. : Юрайт, 2017 (Il’yin I. V., Leonova O. G. Politicheskaya globalistika [Political Globalistics]. Moscow : Yourayt, 2017).

Barthwal-Datta M., Chacko P. The Politics of Strategic Narratives of Regional Order in the Indo-Pacific: Free, Open, Prosperous, Inclusive? // Australian Journal of International Affairs. 2020. Vol. 74. No. 3. Pp. 244-263. DOI: 10.1080/10357718.2020.1744517.

Chacko P. The Rise of the Indo-Pacific: Understanding Ideational Change and Continuity in India's Foreign Policy // Australian Journal of International Affairs. 2014. Vol. 68. Issue 4. Pp. 433-452. DOI: 10.1080/10357718.2014.891565.

Doyle T., Rumley D. The Rise and Return of the Indo-Pacific. London : Oxford University Press, 2020.

Dutta A. India Doesn't Know How To Counter 'China's Grand Strategy' // South Asia Monitor. 2016. May 12. URL: https://www.eurasiareview.com/12052016-india-doesnt-knowhow-to-counter-chinas-grand-strategy-analysis/ (дата обращения/accessed: 15.05.2020). 
Ensuring secure seas: Indian maritime security strategy. Indian Navy, Naval strategic publication (NSP). 2015. URL: https://www.indiannavy.nic.in/sites/default/files/Indian_Mari time_Security_Strategy_Document_25Jan16.pdf (дата обращения/accessed: 10.08.20).

Grieco K. A. The 2018 National Defense Strategy: Continuity and Competition // Strategic Studies Quarterly. 2018. Vol. 12. No. 2. Pp. 3-8.

Heydarian R. J. The Indo-Pacifc: Trump, China, and the New Struggle for Global Mastery. Singapore : Palgrave Macmillan, Springer Nature Singapore Pte Ltd., 2020.

India and China at Sea: Competition for Naval Dominance in the Indian Ocean / ed. by D. Brewster. New Delhi : Oxford University Press, 2018.

Jakobson L., Medcalf R. The Perception Gap: Reading China's maritime strategic objectives in Indo-Pacific Asia. Report. Sydney : Lowy Institute for International Policy, 2015.

Joint Indian Armed Forces Doctrine. Directorate of Doctrine, Headquarters Integrated Defence Staff, Ministry of Defence. Second Eddition. 2017. URL: http://bharatshakti.in/wpcontent/uploads/2015/09/Joint_Doctrine_Indian_Armed_Forces.pdf (дата обращения/асcеssed: 18.08.2020).

Kaplan R. Monsoon: The Indian Ocean and the Future of American Power. New York : Random House Trade Paperbacks, 2010.

Kumar S., Verma S. S., Shah S. H. Indo-US Convergence of Agenda in the New IndoPacific Regional Security Architecture // South Asia Research. 2020. Vol. 40(2). Pp. 215230. DOI: 10.1177/0262728020915564.

Li L. The New Trend of India's Rising as a Great Power // Contemporary International Relations. 2018. Issue 2 (March - April). Pp. 43-49.

Mathur S. China, Indian Ocean and the Nuclear Deterrence: The Destabilizing Effect. Institute of Peace and Conflict Studies. 2014. URL: https://studylib.net/doc/8105940/thedestabilizing-effect---institute-of-peace-and-conflict (дата обращения/accessed: 12.05.2020).

Medcalf R. In Defence of the Indo-Pacific: Australia's New Strategic Map // Australian Journal of International Affairs. 2014. Vol. 68(4). Pp. 470-483. DOI: 10.1080/10357718. 2014.911814.

Mohan C. R. Samudra Manthan: Sino-Indian Rivalry in the Indo-Pacific Region. Washington, D.C. : Carnegie Endowment for International Peace, 2012.

Mukherjee T. China's Maritime Quest in the Indian Ocean: New Delhi's Options. The Diplomat. April. 2018. URL: https://thediplomat.com/2018/04/chinas-maritime-quest-inthe-indian-ocean-new-delhis-options/ (дата обращения/accessed: 04.05.2019).

Naidu G. V. C. 2014. C. 'Indo-Pacific' as a New Template of Analysis. Debate 'IndoPacific: an Emerging Geopolitical Construct. India's Interests, Stakes and Challenges // Indian Foreign Affairs Journal. 2014. Vol. 9(2). Pp. 102-107.

New Regional Geopolitics in the Indo-Pacific. Drivers, Dynamics and Consequences / ed. by P. Chako. London; New York : Routledge, Taylor and Francis Group, 2016.

Pan C. The 'Indo-Pacific' and Geopolitical Anxieties About China's Rise in the Asian Regional Order // Australian Journal of International Affairs. 2014. Vol. 68(4). Pp. 453-469. DOI: $10.1080 / 10357718.2014 .884054$.

Pant H. V., Rej A. Is India Ready for the Indo-Pacific? // The Washington Quarterly. 2018. Vol. 41(2). P. 47-61. DOI: 10.1080/0163660X.2018.1485403. 
Pardesi M. S. The Indo-Pacific: A 'New' Region or the Return of History? // Australian Journal of International Affairs. 2020. Vol. 74(2). P. 124-146. DOI: 10.1080/10357718.20 19.1693496.

Rajeev N. A Holistic Approach to India's Nuclear Doctrine // The Diplomat. 2017. May 24. URL: https://hediplomat.com/2017/05/a-holistic-approach-to-indias-nuclear-doctrine/ (дата обращения/accessed: 15.08.2020).

Scobell A. Constructing a U.S. - China Rivalry in the Indo-Pacific and Beyond // Journal of Contemporary China. 2020. DOI: 10.1080/10670564.2020.1766910.

Scott D. The "Indo-Pacific" - New Regional Formulations and New Maritime Frameworks for US - India Strategic Convergence // Asia-Pacific Review. 2012. Vol. 19(2). 2012. P. 85-109. DOI: 10.1080/13439006.2012.738115.

Summary of the National Defense Strategy. 2018. Sharpening the American Military's Competitive Edge. (Part 'Strengthen Alliances and Attract New Partners'). URL: https:// introvertum.com/wp-content/uploads/2018/01/2018-National-Defense-Strategy-Summary.pdf (дата обращения/accessed: 10.08.2019).

Singh A. G. India, China and the US: Strategic Convergence in the Indo-Pacific // Journal of the Indian Ocean Region. 2016. Vol. 12(2). Pp. 161-176. DOI: 10.1080/194808 81.2016.1226752.

The Origin of 'Indo-Pacific' as Geopolitical Construct. Insights from Gurpreet Khurana. The Interview of Mercy A. Kuo with Dr. Gurpreet S. Khurana: The Diplomat. 2018. January 25. URL: https://thediplomat.com/2018/01/the-origin-of-indo-pacific-as-geopoliti cal-construct/ (дата обращения/accessed: 12.04.2019). 